\title{
Towards Psychosocial Well-Being in Historic Urban Landscapes: The Contribution of Cultural Memory
}

\author{
Fatmaelzahraa Hussein ${ }^{1,2, * \mathbb{C}}$, John Stephens ${ }^{1} \mathbb{D}$ and Reena Tiwari ${ }^{1}$ \\ 1 School of Design and Built Environment, Curtin University, Perth, WA 6845, Australia; \\ j.stephens@curtin.edu.au (J.S.); r.tiwari@curtin.edu.au (R.T.) \\ 2 Department of Architectural Engineering, High Institute of Engineering and Technology, \\ El Behira 22699, Egypt \\ * Correspondence: f.hussein@postgrad.curtin.edu.au; Tel.: +61-46-960-6078
}

Received: 29 September 2020; Accepted: 6 November 2020; Published: 9 November 2020

\begin{abstract}
A crucial element in the human search for well-being is achieving a sense of identity within, and belonging to, the landscape in which we live. Landscape should be understood as not only the visible environment but the affective values we attach to it and how we shape it in our mind's eye. These inner reflections of our landscapes constitute one of our richest archives, in particular, in terms of creating and passing down to future generations our cultural memories. The current paper is a review of literature on the concepts of urban heritage conservation, and, in particular, the development of the historic urban landscape (HUL) approach, with reference to the role and contribution of cultural memory and its presence in the urban landscape. We also investigate how the notions of place attachment and identity interrelate with cultural memory to elucidate how such interrelations can contribute to human psychosocial well-being and quality of life (QOL). This review points to the neglected role of cultural memory in the maintenance of psychosocial well-being in HULs, a topic which requires further research to deepen our understanding about its importance in urban environments.
\end{abstract}

Keywords: place attachment; place identity; quality of life; sense of place; urban conservation

\section{Introduction}

A recent strand in well-being research has focused on the crucial role of health and comfort within the human environment [1]. Well-being can be understood as comprising both physical (i.e., tangible) and psychosocial (i.e., intangible) elements [2]. Within the latter category, affect, the impact of lived experience, and the influence of the psyche can all mould how humans interpret and interact with the spaces in which they live. Memory, likewise, is important in forming attitudes toward environments, as humans call on stored memory data in built environments to retain and re-enact behaviours and attitudes [3]. In this context, this paper aims to review relevant literature to elaborate on the role of cultural memory in the value ascribed by humans to their landscapes and its role in achieving psychosocial well-being. In this paper, historic urban landscapes (HULs) provide an interactive ground on which these processes take place and will need to be discussed at length to establish the relations between cultural memory, people and the urban landscapes they inhabit. Here, cultural memory is seen as a dynamic - " an ongoing process of remembrance and forgetting, in which individuals and groups continue to reconfigure their relationship to the past and hence reposition themselves in relation to established and emergent memory sites" [4]. This means that cultural memory has important and reciprocal connections to space and place.

To achieve our aim, we need to investigate the emergence and nature of HULs and what cultural memory connections humans have to place and historic landscapes. In addition, whether the aspects 
of the past that HULs (as a repository of memories) encompass have an important role in maintaining cultural memory and, consequently, psychosocial well-being. In the following sections, we will review three concepts to help answer the above questions. These are the HUL approach to conservation, the important role of cultural memory in historic urban landscapes and the crucial role that psychosocial well-being has in placemaking and the experience of urban places. Towards the end of this review, we aim to draw the attention of urban planners and researchers to the importance of the intangible values of place, focusing mainly on cultural memory and its potential contribution to psychosocial well-being in our urban contexts and quality of life (QOL).

\section{The Emerging Historic Urban Landscape Approach}

Haggag and Rashed [5] define conservation as "the careful management of a limited resource, in order to ensure efficiency and continuity of use. The end of World War II ushered in a period of redevelopment and planned destruction of historic cities on a global scale, which ultimately triggered a realisation among heritage conservation professionals, city planners and architects that historic urban fabric was in dire need of protection if traditional cultural identities were to be preserved. The threat of unsympathetic modernist redevelopment of historic urban areas "signified a destruction and loss of connection to past and place" [6]. In this setting, heritage conservation can be regarded as the processes of protecting and maintaining a place so that its cultural significance is retained [7]. Several governmental and non-governmental organisations (NGOs) were established to promote heritage conservation, including UNESCO, ICOMOS, ICOM and ICCROM. These bodies aimed to formulate policies to underpin national and international legislation to safeguard historic cities during a period of massive economic and social change. In particular, major conservation agencies added to a body of conservation charters designed to serve as guidelines for conservation practice that had been initiated in the late 19th century, summarised as follows [8].

- Society for the Protection of Ancient Buildings (SPAB) Manifesto 1877: The manifesto called for the need to restore and value the historical and picturesque features of ancient architecture and avoid the destruction of building fabric.

- Athens Charter 1931: The first charter systematically laid out a set of scientific principles to inform the preservation and restoration of historic monuments internationally.

- The Venice Charter 1964: Updated the Athens Charter by extending historic monuments to include both historic urban and rural fabrics.

- European Charter of the Architectural Heritage 1975: Extended the concept of the Venice charter to recognise social and economic values.

- Washington Charter 1987: Reinforced the concept of urban and rural environments as historic monuments and specified that conservation measures should leverage a multidisciplinary framework and be an integral part of planning at urban and regional levels.

- Burra Charter 1999: Added to guidance on how places of cultural value could be selected for conservation and formulated best conservation practice.

- The Charter on the Built Vernacular Heritage, ratified by ICOMOS 2000: Guided the conservation and management of buildings of cultural significance.

Each of these charters attempted to critique and refine the idea of cultural heritage conservation and chart a way between the development of the built environment and the maintenance of cultural heritage and the community sense of belonging to a place. The HUL approach draws on these and others to provide a holistic approach to the fragmentation and decay of historic urban areas. It draws on several disciplines to formulate an inclusive and holistic model to heritage management and practice and is designed to be used amid the constantly changing conditions which characterise today's towns and cities [9].

In the context of this paper, the conservation of historic sites should be understood not only as just preserving the forms of historical monuments but also as a vessel in which traditional attitudes and 
values can be kept alive and traditional behaviours can continue to be practised [10]. This concept of conservation takes tradition to be an active form of authentic cultural heritage, rather than something passive that belongs in the past [11]. For ICOMOS (2002), cultural heritage is "an expression of the ways of living developed by a community and passed on from generation to generation, including customs, practices, places, objects, artistic expression and values" [12], while for Feather [13], it is "a human creation intended to inform". The idea of cultural heritage spurred the authors of the 1964 Venice Charter to take conservation beyond mere physical maintenance and apply it to the wider urban environment. This gave rise to the notion of urban conservation, defined by Orbasli $[8,14]$ as "all the processes of looking after a place so as to retain its cultural significance; it includes maintenance and may vary according to circumstances, including preservation, restoration, reconstruction and adaptation, and will commonly be a combination of more than one of these". Moreover, as researchers including Haggag and Rashed and Orbasli [5,15] observe, urban conservation also encompasses cultural heritage issues such as the management of cultural resources, continuity of use of urban structures, and how efficiently any changes to these are introduced and monitored.

Pendlebury followed by Suttona and Fahim [16,17] researched the conservation of historic areas in the UK and Cairo, respectively, and mentioned three principal approaches to the practice of urban conservation. The first of these derives from the SPAB tradition started in 1877, which privileges the retention of historic fabric above all other considerations and, therefore, advocates that only the most conservative repairs are carried out. The second is the urban morphological approach, which derives from the study of how a settlement developed over the course of its history on the basis that its physical development is a reflection of its social and cultural development and the materialisation of its "spirit". The three practices under this approach are restoration, renovation and rehabilitation. Lastly, the visual management approach privileges urban design, including aesthetics, over the retention or rehabilitation of historic elements.

Most conservation approaches aim to protect and preserve historic physical urban fabric. However, finding conservation approaches that aim and manage to protect social structures is more problematic, despite a widespread acceptance that, as Haggag and Rashed [5] point out, conservation consists of "the action necessary to preserve anything of acknowledged value", not just physical objects. Instead, there has been a tendency among both researchers and practitioners to highlight tangible values, such as architectural elements, over intangible ones, such as emotional, social, cultural and psychological connections between humans and the landscapes they inhabit. It is this imbalance which has encouraged the emergence of the HUL approach since the Vienna Memorandum was published in 2005 (see Figure 1).

UNESCO [18] defines the HUL approach as an attempt to manage changes made to historic urban fabric in a way that respects the complex relations between the strata of natural, cultural, and tangible and intangible elements, which together shape a city. Further, the HUL approach is both inspired by and continues to privilege the traditions practised by local urban communities, drawing on a bottom-up understanding of ways of life in particular cities and the collective memories and practices attached to particular places [19]. Di and De [20] enumerate three specific conservation policies within the HUL approach:

(1) Urban and cultural environments are approached as multilayered living organisms, rather than mere sites of interest to be conserved.

(2) Using an integrative, multistakeholder approach to the management of change, rather than an outdated reliance on "mono-disciplinary processes of restoration" and direction by heritage experts and urban design professionals.

(3) Aiming to enhance value, rather than merely ensure preservation through a joined-up approach, which encompasses socioeconomic development. 
HUL Concept Development

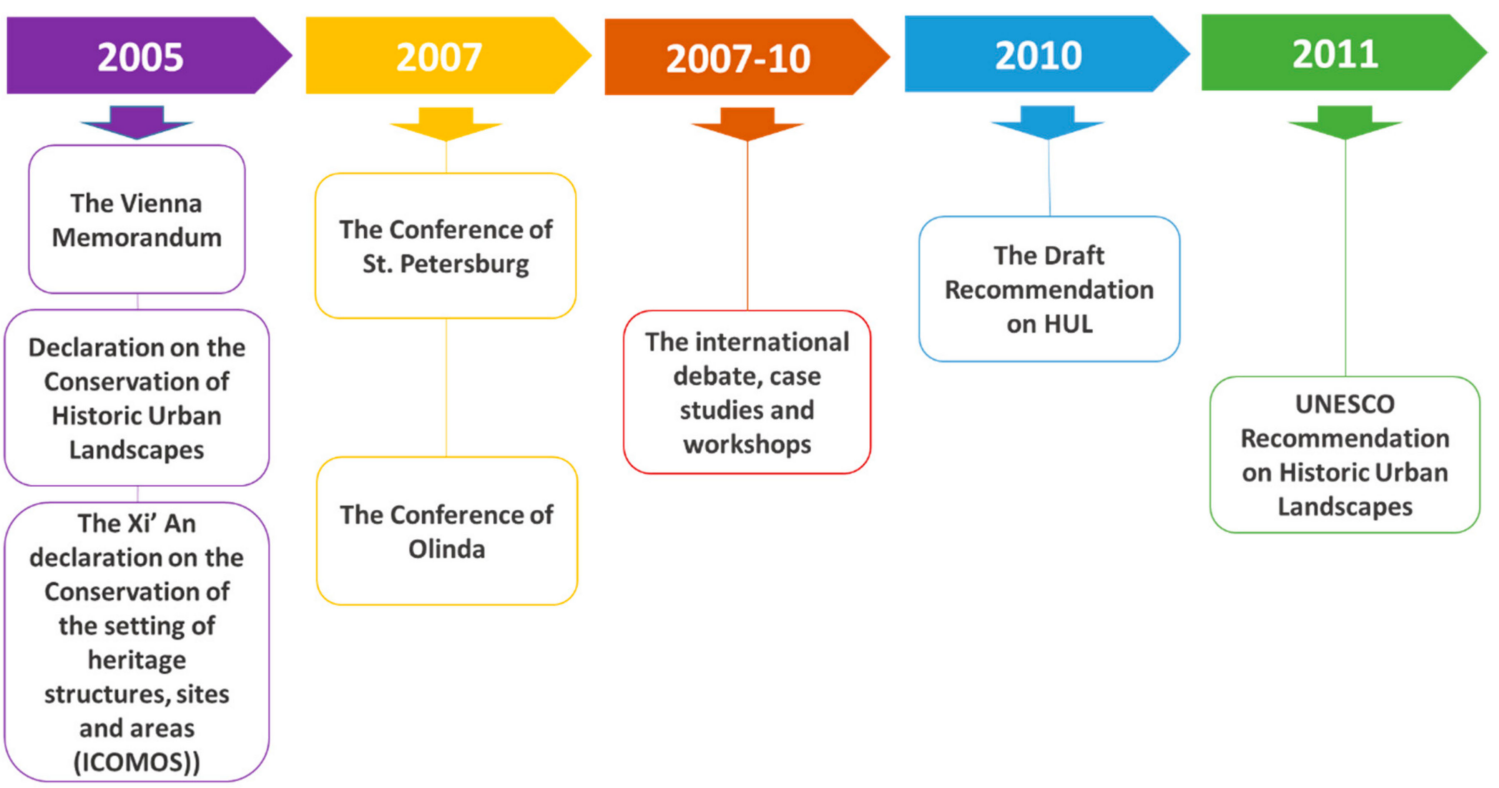

Figure 1. Diagram showing the sequential historical events for emerging and developing the concept of the historic urban landscape (HUL) approach. Adapted from [18].

\subsection{Historic Urban Landscape, Recent Experiences and Evaluation}

The HUL Guidebook emphasises that "successful management of urban heritage in complex environments demands a robust and continually evolving toolkit" and six crucial steps are listed as follows [18]:

(1) Full and detailed surveys and maps of the natural, cultural and human resources within a given environment must be carried out.

(2) All identified stakeholders must participate in identifying the values to be preserved for future generations and how this is to be done.

(3) The means identified for passing on values must be assessed in terms of vulnerability to climate change and socioeconomic change.

(4) The assessments of value and vulnerability must be integrated into wider considerations of urban development at planning, design and implementation stages.

(5) The necessary actions to conserve and develop the identified attributes must be prioritised.

(6) Each identified intervention must be matched with the necessary partnerships and local management structures to ensure coordination between stakeholders, including between private and public sectors.

Where the Guidebook is deficient, however, is in offering assessment metrics to evaluate the success of each stage of the HUL approach, as well as to gauge whether the necessary delicate balance between development and heritage conservation is achieved [21]. Of the eight case studies cited in the Guidebook as examples of best practice (Ballarat, Australia; Shanghai and Suzhou, China; Cuenca, Ecuador; Rawalpindi, Pakistan; Zanzibar, Tanzania; Naples, Italy; Amsterdam, The Netherlands), only Cuenca, Rawalpindi and Amsterdam devised and experimented with evaluation measures indicating a lack of consideration for testing quality of life issues in the HUL assessments of these places.

In the HUL-approach project implemented in Cuenca, a participative quality assessment that focused on the second stage of the six steps outlined above was carried out, namely, the multistakeholder identification of what constitutes cultural value. In Rawalpindi, a vulnerability assessment was also carried out. First, residents were interviewed in the community and invited to attend participative meetings to carry out the same process of identification, after which the socioeconomic vulnerability of 
the identified attributes was assessed with reference to the cultural, commercial, and religious urban landscape, including the resilience of traditional occupations and the role played by the bazaar in urban life. In Amsterdam, a more sophisticated evaluation approach was taken: a classification-based policy analysis instrument was designed to reveal the application of urban policies in relation to HUL across four dimensions: attributes (what), values (why), actors (who) and process (how), as identified in workshops attended mainly by heritage and urban government professionals.

There are several flaws in each of these assessment processes, for example, not consulting all stakeholders at all stages [21] and focusing on the opinions of experts rather than local residents [22]. In all these cases, the impacts of conservation/regeneration plans have not been addressed, such as the effects of the projects on the well-being, health and quality of life (QOL) of HULs [23]. This indicates that the consideration of psychosocial well-being is still an outlier in the assessment of HULs; this is a situation that needs remedy.

\subsection{Historic Urban Landscapes and Memory}

The Vienna Memorandum, issued by UNESCO in 2005, defines HULs as ensembles "of any group of buildings, structures and open spaces, in their natural and ecological context" that has "shaped modern society and has great value for our understanding of how we live today" [11]. In 2011, UNESCO clarified that any urban area should be understood as the result of strata formed over a period of time that bring together culture, nature and other attributes. This point was reinforced by Bandarin [24], who observes that HUL is one of many urban elements that underpin the formation of national or local identity in their role of repositories of memory and social value, as well as being generators of income through touristic and other activities. In concordance with the aforementioned relation between HUL and memory, Tim Inglod [25] introduced the idea of "time and landscape", trying to connect the anthropologist view to the archeological view when dealing with landscapes. He explained that human life is a process that involves the passing of time connected to the forming of landscapes. While explaining his "time and landscape" vision, Ingold indicated that "landscape is constituted as an enduring record of - and testimony to-the lives and works of the past generations who have dwelt within it, and in so doing, have left there something of themselves" and he named this deep viewpoint of understanding landscape as "dwelling perspective".

Moreover, the HUL approach does not refer only to a particular group of monuments or streets, as commonly implied by the label "historic centre", but encompasses the wider urban hinterland and setting in topographical, geological, hydrological and geomorphological terms, as well as buildings of all ages, infrastructural elements such as transport, public spaces and utilities, and ways in which these are used and understood by inhabitants. Moreover, it "includes social and cultural practices and values, economic processes and the intangible dimensions of heritage, as related to diversity and identity" [18].

One of these values is "memory". When memory is understood as being of social value, the urban landscape can be perceived as a culturally constructed collection of memories, practices and effects, or, as Raadik-Cottrell [26] points out, "the medium through which multiple histories are simultaneously remembered and forgotten". We become attached to the places in which we live because they elicit nostalgia in us and trigger our memories [27]. In this sense, the landscape is a rich historical archive [28]: far from being a mere collection of streets and houses, it is a database in which we store and access individual, family and community memories [11]. Hence, personal and collective memory cannot be separated from landscape, and landscape becomes a representation and record of our beliefs, attitudes and practices.

HUL can thus be understood as a cultural construct, which holds our memories and helps give meaning to our current lives [28]. Clearly, not all memories are pleasurable: many urban landscapes will also evoke feelings of pain, loss, conflict, dispossession, and war [28,29]. Sometimes, these landscapes are referred to as "dissonant/difficult" heritage sites, places that recall the politics of the past in the present and reveal dark or painful events [30]. Curti [31] argues that these sites are reminders of pain 
and destruction and are, as quoted, "always performed and felt between, in and through bodies and thus always work through entangled forces of emotion, affect and memory". It recalls what is known as "collective trauma", which refers to a tragedy represented in collective memories [32]. In spite of the fact that the memory of trauma may cultivate a distressful and fearful post-traumatic viewpoint, it may also investigate the meaning obtained from the trauma, a meaning that elaborates the traumatised group's resilience and their ability to rehabilitate after the tragedy [33]. Communities, rather than individuals, have felt many such feelings, and thus, community experience can be seen as giving rise to the sense of place of an individual.

\section{Placing Memory and Cultural Memory}

Boyer [34] explains that memory refers to the human ability to retain, revive and recall previously-lived events and, hence, keeps us connected with the past. But is memory, and the connection with the past which it facilitates, really necessary? For Nora [35], memory means a constant temporal connection between present and past experiences, whereas history, in contrast, is merely how we represent the past. Although there has been much debate on this issue, the consensus is that memory is indeed vital to human well-being as it gives the necessary structure to deal with instability and change in the present [36]. Otherwise put, without the past, we cannot deal with the present: we can only understand the objects and structures we experience now by drawing on how we previously dealt with them [37]. In this way, each individual is guided by their memories, and memory constantly strengthens temporal and spatial connections [38]. Our recollection of any given occurrence concerns the environment within which it happened, which gives meaning to our lives and sense and direction to the temporal and spatial connections we are constantly making [29]. Whether individual or collective, memory has strong links to present lived experience, differentiating memory and history. For Boyer, "the activity of recollection must be based on spatial reconstruction" [34]. Collective or cultural memory occurs when multiple individuals recall and share the memory of a space, event or experience $[29,35]$.

\subsection{Cultural Memory}

Cultural memory can be defined as the remembrance of events connected to objects and places experienced by individuals or groups operating within social frameworks [39]. As collective memory has been described as a repository of culture, there has been a slippage between the terms "collective memory" and "cultural memory" [40].

Multiple disciplines have approached the subject of cultural memory, including psychology, sociology and geography. Far fewer, however, have addressed the interrelation between cultural memory, use of space and urban heritage. The term "collective memory" (or memoire collectif) was coined by the French sociologist Maurice Halbwachs in The Social Frameworks of Memory and On Collective Memory. Halbwachs [41] took collective memory to be distinct from individual memory, which he characterised as "personal" and "autobiographical", as opposed to "social" and "historical". Moreover, Halbwachs explained that an individual's "autobiographical memory" brought back events or feelings experienced by that person, whereas "historical memory" operated more widely, encompassing contextual information. Cotoi [42] expanded on this distinction by positing that while cultural memory is both external and personal, collective memory is without connection to a neural system. Halbwachs points out that an individual will have difficulty describing an event without simultaneously imagining the location in which it occurred, as "the past is mapped in the minds according to its most unforgettable places" [27].

Historian Pierre Nora [35] addressed the study of spatial collective memory from the perspective of geography and the built environment, examining the capacity of certain locations to capture emotions and incarnate national memories. Nora's "spatial collective memory" was developed by scholars who posited the essentially social nature of cultural memory, revealing the crucial role of urban spaces as both the location of occurrences and the soil in which memories and identities grow [29]. 
Cultural memories must necessarily be place-specific; hence, remembering and reconstructing them relies on a continued connection with the place in which they were first formed [28]. A memory is "cultural" because it must be institutionalised to exist, and it is a "memory" because it is a function of socialisation [42], becoming a melding of dynamic histories and collective recollections that occupy a space somewhere between official versions of history and personal reminiscence [40].

Architectural theorist Aldo Rossi's concept of "urban memory" was inspired by his readings of Halbwachs and Nora. This new approach to urban cultural memory sees significant elements in urban landscapes, such as places of worship, public spaces, monuments and so forth as palimpsests on which memories have been inscribed [39], which originate from "shared past communications ... anchored in the life-worlds of individuals who partake in the communal life" [43]. Urban memory, therefore, aligns with Hamilton's [44] definition of cultural memory as a record of "resemblances, similarities that is kept alive by continuous reworking and transmission".

The City of Collective Memory [34] reworked Rossi's urban memory to find a link between cultural memory and the transformation of urban landscapes. In addition, it finds that traces of earlier incarnations of urban life can be read in a city's architecture, which hence becomes a form of collective memory expressed through sites of public importance as well as the configurations of everyday use [45]. Moreover, she links the development of images of a city to the everyday life experienced within it and relates how this, as well as economic and political affairs, also has a bearing on cultural memory [46]. Above all, Boyer [34] emphasises that if memory cannot be linked to lived experience, it will fail in its role of connecting us to our past. Furthermore, and crucially, the difference between history and memory will be eroded, and the past will become fragmented. Her thinking has been added to by the work of other writers on cultural memory, such as Isidora's [47] concept that cultural memory consists of mnemonics devised by and uniting cultural groups to retain and reinforce their identity over time.

It appears that every society and community has cultural memory and that it works to standardise and regulate communal life. Different types exist: for example, as Legg [48] observes, nationalist cultural memory is used to tie a national identity to a geographically-specific place. In all cases, however, city residents draw on the link between cultural memory, everyday life and urban environment to understand and retain their own past and strengthen their attachment to specific locations [49]. The more value is ascribed to cultural memory, the greater the attachment to place; hence, place identity is privileged above other types of identity.

\subsection{Place Attachment and Place Identity}

Generally, researchers agree on the distinctions between space and place, as well as the definition of place, as a space with meanings [50-52]. Mihaylov and Perkins [53] define place as having symbolic, cultural or functional meanings with attributes that "give it a distinct identity in the minds of dwellers; what belongs here, what fits in the place, what makes it unique". This view of place is useful as it establishes place as having functions that link memory, experience, emotion and identity. However, there is no consensus in the literature as to how bonds between people and place (e.g., attachment, identity, sense of place, dependence) can be measured. Nonetheless, most scholars agree that achieving psychological balance and adjustment requires emotional bonds of place to be developed [54] and, moreover, that such bonds mitigate against the identity crises suffered by people bewildered by change [55].

"Place attachment" is understood to refer to the connections individuals feel with particular places $[50,56,57]$ or the degree to which an individual values their bond with a given environment $[58,59]$. Lewicka saw place attachment as an emotional relationship that could be translated into pride taken by individuals in where they lived, particularly its appearance [60], while Hidalgo and Hernandez [57] posit that strong attachments will develop when individuals feel confident in their right to engage in activities connected with a certain place.

Several scholars have conceptualised place attachment as consisting of three distinct elements, namely, affective, cognitive and practical [50,61]. The first (affective) is an emotional element, whereas 
the second (cognitive) concerns place-related thought, knowledge and belief. The third (practical) concerns the behaviours and activities undertaken at a place that contributes to a person's regard for a place [61]. Place attachment can also arise from feelings of pleasure related to being in a place and the sadness felt at departing from it [62]. Hence, people become attached to a place through experiencing both positive and negative aspects and not merely because it enables some function of communal life to be satisfactorily carried out [50]. Place attachment is valuable because it keeps alive both the attraction and meaning of places for their users by ensuring that significant and familiar characteristics are not destroyed [63].

For Rubinstein and Parmelee [64], place attachment can be broken down into four dimensions. The first is "knowledge", by which the authors mean being aware of a place but having no strong personal feelings or memories attached to it. Thereafter, a "personalized attachment" is a memory of some personal experience which occurred in a particular place, while "extension" occurs when an individual is psychologically or emotionally involved with the place in more than one way. Finally, "embodiment" entails a blurring between the boundaries of self and place, such that an individual's idea of him/herself is entirely place-dependent. Under this understanding, attachment to a given place will grow when users perceive it holds more significance for, and is better known to, them, better meets their functional requirements and gives them more help in achieving behavioural goals than any other place [65]. This points to place identity as another important bond between people and places.

Place identity is conceptualised by Proshansky and Jaskiewicz $[60,66]$ as the degree to which an individual's self-concept is moulded by a place and its attributes. However, as identity is comprised of two distinct dimensions-"continuity" (i.e., similarity) and "distinctiveness" (i.e., uniqueness) [67]—place identity can also be conceptualised as the attribute which underpins and ensures the uniqueness and continuity of a specific place over a period of time [62]. Anton and Lawrence [68] suggest that a place that possesses identity is one which evokes in us feelings of specialness, happiness, being in control, and alignment with our self-conceits.

There is little consensus in the literature about the relationship between place attachment and place identity. Whereas some scholars see place identity as one of several components which make up place attachment [69], others regard the two as distinct concepts [67]. The current review takes the latter view while accepting that the close inter-relations between them are vital parts of the overarching concept of "sense of place" [70]. The understanding that they are discrete concepts is backed by Relph's [52] observation that an individual can feel an attachment to a place for a range of reasons, whether affective or otherwise, while forming the identity of the place is different as it varies according to the agreed individual or group image formed for a place.

To understand how place identity is constructed, it is vital to grasp not only the socioenvironmental values embraced in the respective society but also how its inhabitants relate to their environment. Grasping this multifaceted relationship between people, place and values enables us to focus as much on psychosocial and emotional senses of place and belonging as on physical attributes [71].

\section{Placing Psychosocial Well-being}

Increasing attention has been paid to the concept of well-being in multidisciplinary sciences; nevertheless, its intangibility renders it hard to pin down and measure in any meaningful way [72]. Various definitions of well-being and possible metrics to assess it have been put forward. Shin and Johnson's [73,74] definition of well-being as "a global assessment of a person's quality of life according to his (sic) own chosen criteria" informs much of recent literature, but raises an equally important question, namely, what is QOL? Defined by the World Health Organization (WHO; [75]) as "an individual's perception of their position in life in the context of the culture and value systems in which they live and in relation to their goals, expectations, standards and concerns", this broad-ranging condition is also inter-related with many other aspects of a person's life, such as physical and psychological health, personal beliefs and goals, social relationships and connections to their environment. One important aspect of the WHO's [76] definition is its emphasis on psychosocial well-being, as this emphasises 
how closely psychological experiences (thoughts, emotions, behaviours) are connected with social ones (relationships, traditions, culture). More recently, the Inter-Agency Network for Education in Emergencies (INEE) suggested that psychosocial well-being derives from accessing a wide range of the attributes and circumstances that confer benefit, such as meaningful participation in society, having happiness and hope, being guided by strong values, as defined within the respective culture, robust social relations, a feeling of support, the life skills necessary to deal with challenges, fulfillment of basic needs such as shelter and safety, and access to necessary services. Given this range of needs and values, psychosocial well-being has been the subject of research across multiple disciplines, including geography and sociology, of which the most relevant to the current paper is sense of place.

\subsection{The Psychosocial Construct of Sense of Place}

Conceptualisations of and frameworks for "sense of place" have been proposed by a range of researchers (e.g., Relph, 1976 [52]; Tuan, 1980 [77]; Steele, 1981 [78]; Eyles, 1985 [79]; Jackson, 1994 [80]; Hay, 1998 [55]). The ancient Romans believed in the genius loci, literally, the spirit that protects a place. Relph (2008) describes spirit of place as the bundle of "inherent properties that lend identity to somewhere", whereas sense of place is "the faculty by which that identity is perceived" [81]. Yi Fu Tuan (1996) similarly differentiates between the concepts by observing that while places "may be said to have "spirit" or "personality", only human beings can have a sense of place" [82].

Understanding a person's sense of place is one means to approach their emotional well-being and response to that place. Steel's (1981) The Sense of Place summarises the relational nature of sense of place in four points, as explained by Cross [83]. Firstly, an individual and their environment stand in a transactional relationship with each other. Individuals take from and give to environments, both actions of which may determine how the environments influence them. Secondly, to have a sense of place, an individual must have a psychological or interactional perception of it, rather than simply a physical one. This is because an environment consists not only of physical attributes but also social ones, which influence how a person experiences it. In other words, to a large extent, places do not have an objective existence outside our perception of them. That said, the sense of place in certain environments is so overwhelming and globally recognised that the majority of individuals there may be influenced in the same way, for example, when visiting the Italian city of Florence or natural wonders such as Victoria Falls. The last and related point is that patterns of long- and short-term impact of sense of place can be discerned.

Steel's development of the concept of sense of place was further elaborated by Hummon [84], who observed its inevitable duality as it involves "both an interpretive perspective on the environment and an emotional reaction to the environment". From Williams and Stewart's [85] systematic review of works in several disciplines, addressing sense of place and the resulting definitions, we gain an understanding of it as an overarching, multidimensional concept that contains five principals for bonding individuals with places, listed as follows:

- $\quad$ Sense of place presupposes an emotional bond forged over time.

- The emotional weight of the values and meanings inherent in sense of place is only readily perceptible to place "insiders".

- Even place insiders may not be conscious of the values they ascribe within sense of place until such values disappear or come under threat.

- The place values and social interactions are a product of consciousness of place-related cultural, historical and spatial values.

- The meanings within sense of place are not static but change over time in a process of construction and reconstruction, in tandem with changes to individual, group and community attitudes and practices. 


\subsection{Sense of Place, Cultural Memory and Psychosocial Well-being}

Scholars studying the effects and understanding of sense of place are faced with multiple space-specific characteristics that hamper generalisability. Datel and Dingemans $[86,87]$ understand sense of place to be the ensemble of meanings, values and symbols associated by an individual or community with a particular location. Eyles [88] suggests that the most common senses of place can be classified as "social", "apathetic-acquiescent", "instrumental" and "nostalgic". In an earlier work, Eyles [79] posited that a nostalgic sense of place resulted from remembering the emotions that had been felt in relation to it, and, therefore, those memories are one element of the construct. The relation between memory and sense of place, and hence with psychosocial well-being, is also suggested by environmental psychology's definition of cognition, namely, awareness of consciousness through memories, feelings, attitudes, preferences, values, behaviours and experiences [89]. For Eisenhauer [90], sense of place consists principally of the social interactions that occurred there and the memories associated with it.

Theoretical models for research on sense of place suggest that psychological, social and environmental aspects of human connection to physical places must all be taken into consideration [91]. From a psychosocial perspective, the wellness, both mental and physical, and range of operations which individuals can carry out must be assessed with reference to the social collective of which they are part [92]. Achieving psychosocial benefit through place-making takes individuals beyond survival to a greater level of well-being as the latter is achieved by satisfying needs related to QOL and psychological stability [93]. This type of benefit is achievable through the place-based approach, the focus of which is on the affective sense of place located in feelings, emotions and behaviours, underpinning the finding that individuals experience place not only physically but also perceptually and psychologically. Moreover, the latter experiences are more important than physicality in determining and comprehending attachment to place and the values ascribed to it. Appreciating the weight of intangibles and emotions in attributing value and sense to place has led to the practice and theory of "place-based planning". This type of planning is important because, first, it links a wide range of human values, uses, experiences and behaviours to specific spatial locations [94], and second, it offers a democratic means of defining and expressing the value ascribed to places by their users [95]. It rests on the understanding that "place values" mirror the ways in which people are positively affected by their environments, given that "to be affected by something is to evaluate that thing" [96] or, in the words of Berberich [97], that values are "expressed in how bodies turn towards things".

Taylor [28] proposes three fundamental components of sense of place: observable activities, observable functions and meanings or symbols. Given that a history of urban existence is largely a tale of a struggle between incipient anarchy, on the one hand, and the maintenance of the established order, on the other, local memories, identity and understanding of how the urban environment is used offer a novel tool of interpretation [98]. Moreover, when personal or place attachments are disrupted or suspended, the ensuing loss and grief are deeply felt [99]; whereas failure to meet the needs of survival may result in injury or even death, failure to meet those of well-being may result in psychosocial distress and related illnesses [93]. Place attachment can, therefore, be conceptualised as contributing positively to the maintenance of place identity and sense of place and, therefore, as a means of promoting the affective well-being and need-satisfaction of urban residents, underling its crucial place in the psychosocial value of place.

\section{Conclusions}

This article aims at reviewing the literature relevant to how humans connect to historic urban landscapes and the role and importance of cultural memory in the development of HULs to help promote psychosocial well-being.

To answer these questions, the article critically reviewed concepts of urban conservation, HUL, cultural memory, place attachment, place identity, sense of place and psychosocial well-being in order to identify their nature and uncover their correlations (see Figure 2). The review showed that our past 
is important as it captures the memories that orients us through our present and creates feelings of certainty and stability within our landscapes. In addition, it showed that there are myriad intangible values that humans can experience in a specific HUL; one of these values is cultural memory, either a good or bad one. This memory contributes to the formation of the number of relationships with a place, such as place attachment and place identity, that leads to a specific emotion toward this HUL. The relation between cultural memory and HULs and the emotions aroused from place attachment and place identity contributes to the formation of the phenomena of sense of place, with its psychological and social constructs, and contribute to psychosocial well-being. Accordingly, the review showed that a direct relationship between cultural memory and HULs has the capacity to maintain psychosocial well-being in these landscapes.

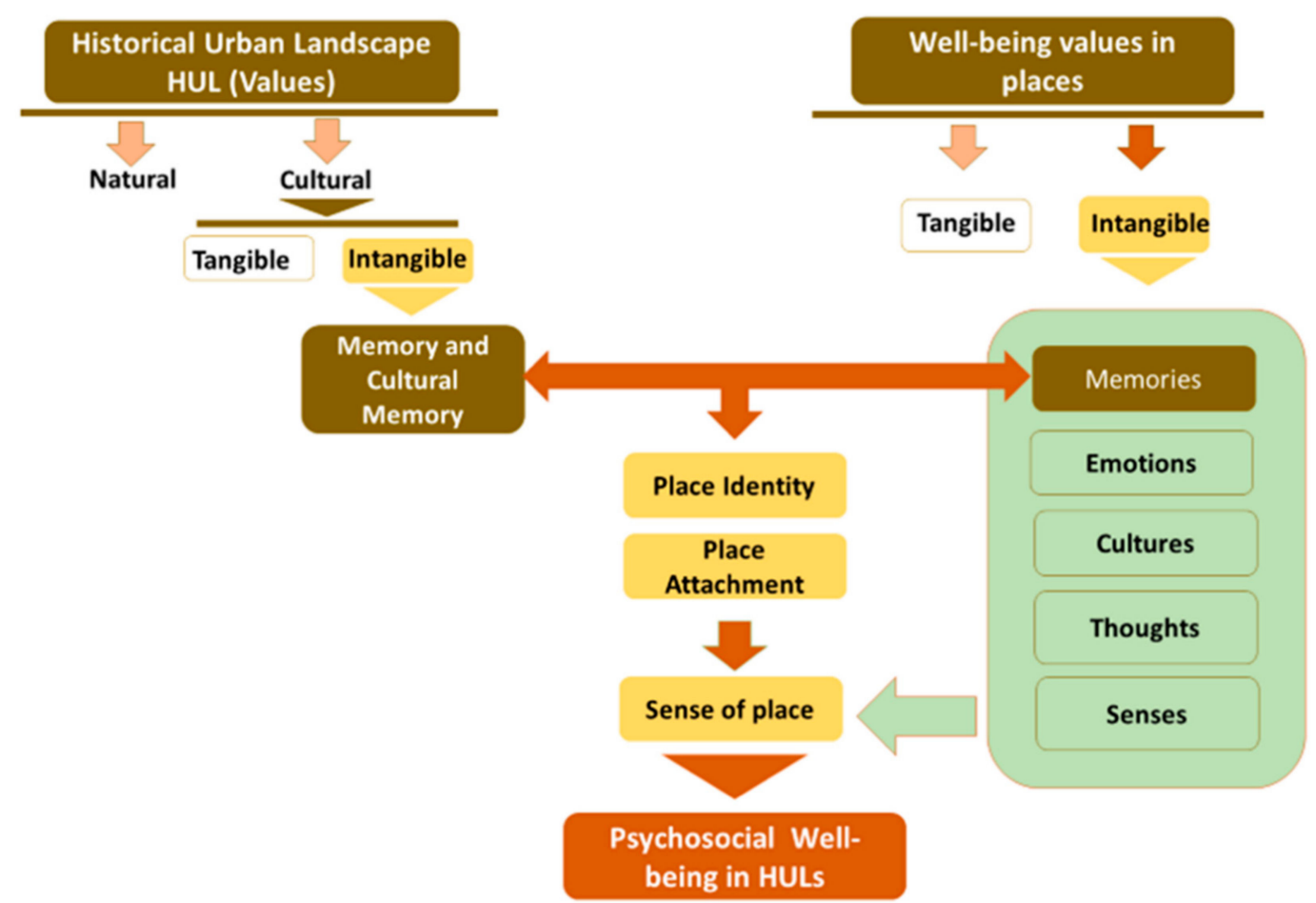

Figure 2. Diagram showing the existing relationships between the concepts of HUL, cultural memory and psychosocial well-being. Source: F.Hussein.

Finally, the paper pointed at less value given to psychosocial well-being by urban planners, despite it being the emotional and intangible construct of quality of life that affects the human psyche and leads to behaviour and social attitudes within a place. More value is often afforded to the tangible physical construct (e.g., good site amenities, lighting, ventilation). Therefore, there is a gap of knowledge in the body of literature on relations between cultural memory and psychosocial well-being. Hence, more research is required to deepen our understanding of the contribution of cultural memory in achieving psychosocial well-being in historic urban landscapes.

Author Contributions: Conceptualization, F.H. and R.T.; Formal analysis, F.H.; Investigation, F.H.; Methodology, F.H.; Resources, J.S. and R.T.; Software, F.H.; Supervision, J.S. and R.T.; Visualization, F.H.; Writing-original draft, F.H.; Writing-review \& editing, F.H., J.S. and R.T. All authors have read and agreed to the published version of the manuscript.

Funding: This research received no external funding.

Conflicts of Interest: The authors declare no conflict of interest. 


\section{References}

1. Ortiz, M.A.; Kurvers, S.R.; Bluyssen, P.M. A review of comfort, health, and energy use: Understanding daily energy use and wellbeing for the development of a new approach to study comfort. Energy Build. 2017, 152, 323-335. [CrossRef]

2. Steg, L.; Berg, A.E.V.D.; de Groot, J.I.M. Environmental Psychology: An Introduction; Steg, E., van den Berg, A.E., de Groot, J.I.M., Eds.; Wiley-Blackwell: Chichester, UK, 2013.

3. Boyer, P. What Are Memories for? Function of Recalling Cognition and Culture. In Memory in Mind and Culture; Boyer, P., Wertsch, J.V., Eds.; Cambridge University Press: New York, NY, USA, 2009; pp. 3-33.

4. Erll, A.; Rigney, A. Introduction: Cultural Memory and Its Dynamics; De Gruyter: Berlin, Germany, $2009 ;$ p. 1.

5. Haggag, M.; Rashed, A. Urban conservation in practice: Evidence from the United Arab Emirates. Alex. Eng. J. 2003, 42, 249-261.

6. Witcomb, A. From the Barracks to the Burrup: The National Trust in Western Australia/Andrea Witcomb and Kate Gregory; Gregory, K., Ed.; UNSW Press: Sydney, NSW, Australia, 2010.

7. The Burra Charter, The Australia ICOMOS Charter for Places of Cultural Significance. In The Australia ICOMOS Charter for Places of Cultural Significance; Australia ICOMOS Incorporated International Council on Monuments and Sites: Melbourne, VIC, Australia, 2013.

8. Rodwell, D. Conservation and Sustainability in Historic Cities. In Reference and Research Book News; Book News: Portland, OR, USA, 2007; Volume 22.

9. UNESCO. New Life for Historic Cities. Historic Urban Landscape Approach Explained 2013. Available online: https://whc.unesco.org/en/news/1026 (accessed on 5 October 2019).

10. Ševčenko, M.B. Adaptive reuse: Integrating traditional areas into the modern urban fabric. In Designing in Islamic Cultures 3; Aga Khan Program for Islamic Architecture; MIT Press: Cambrige, MA, USA, 1983.

11. Lim, J.H. Conservation approaches to the historic urban landscape in the era of globalization: In the same bed but with different dreams? Hist. Environ. 2011, 23, 56-60.

12. ICOMOS. ICOMOS World Report on Monuments and Sites in Heritage at Risk 2002/2003; Petzet, M., Ed.; ICOMOS UK: London, UK, 2002.

13. CiD. What Is Cultural Heritage. 2018. Available online: http://www.cultureindevelopment.nl/Cultural_ Heritage/What_is_Cultural_Heritage (accessed on 24 October 2018).

14. Orbasli, A. Tourists in Historic Towns: Urban Conservation and Heritage Management/Aylin Orbasli; E\&FN Spon: New York, NY, USA, 2000.

15. Orbasli, A. Architectural Conservation: Principles and Practice; Orbasli, A., Ed.; Blackwell Science: Oxford, UK, 2008.

16. Pendlebury, J. The Conservation of Historic Areas in the UK: A Case Study of "Grainger Town", Newcastle upon Tyne. Cities 1999, 16, 423-433. [CrossRef]

17. Sutton, K.; Fahmi, W. The rehabilitation of Old Cairo. Habitat Int. 2002, 26, 73-93. [CrossRef]

18. UNESCO. The HUL Guidebook. In Proceedings of the 15th World Conference of the League of Historical Cities in Bad Ischl, Bad Ischl, Austria, 7-9 June 2016.

19. Torre, C.; Perchinunno, P.; Rotondo, F. The Evidence of Links between Landscape and Economy in a Rural Park. Int. J. Agric. Environ. Inf. Syst. (IJAEIS) 2012, 3, 72-85.

20. Di Palma, M.; De Rosa, F. Historic Urban Landscape Approach and Port Cities Regeneration: Naples between Identity and Outlook. Sustainability 2013, 5, 4268-4287.

21. Gravagnuolo, A.; Girard, L.F. Multicriteria Tools for the Implementation of Historic Urban Landscape. Kval. Inovácia Prosper. 2017, 21, 186. [CrossRef]

22. Ji, X.; Shao, L.; Du, Y. Collaborating with Local Communities to Identify Improvement Priorities for Historic Urban Landscape Based on Residents' Satisfaction: An Application of Asymmetric Impact-Performance Analysis in Dandong, China. Sustainability (Basel, Switzerland) 2020, 12, 1463. [CrossRef]

23. Carone, P.; De Toro, P.; Franciosa, A. Evaluation of Urban Processes on Health in Historic Urban Landscape Approach: Experimentation in the Metropolitan Area of Naples (Italy). Kval. Inovácia Prosper. 2017, 21, 202. [CrossRef]

24. Bandarin, F. The Historic Urban Landscape: Managing Heritage in an URBAN Century; Bandarin, F., Van Oers, R., Eds.; Wiley Blackwell: Hoboken, NJ, USA, 2012.

25. Ingold, T. The temporality of the landscape. World Archaeol. 2010, 25, 152-174. [CrossRef] 
26. Raadik-Cottrell, J. Cultural Memory and Place Identity: Creating Place Experience; Donnelly, M., Dickinson, G., Taylor, P., Vaske, J., Eds.; ProQuest Dissertations Publishing: Ann Arbor, MI, USA, 2010.

27. Hoteit, A. Role of the Landscape in the Preservation of Collective Memory and the Enhancement of National Belonging. Can. Soc. Sci. 2015, 11, 42-49.

28. Taylor, K. Landscape and Memory: Cultural landscapes, intangible values and some thoughts on Asia. In Proceedings of the 16th ICOMOS General Assembly and International Symposium: Finding the Spirit of Place-between the Tangible and the Intangible, Quebec City, QC, Canada, 29 September-4 October 2008.

29. Ardakani, M.K.; Oloonabadi, S.S.A. Collective memory as an efficient agent in sustainable urban conservation. Procedia Eng. 2011, 21, 985-988. [CrossRef]

30. Drozdzewski, D.; Waterton, E.; Sumartojo, S. Cultural memory and identity in the context of war: Experiential, place-based and political concerns. Int. Rev. Red Cross (2005) 2019, 101, 251-272. [CrossRef]

31. Curti, G. From a wall of bodies to a body of walls: Politics of affect|Politics of memory|Politics of war. Emot. Space Soc. 2008, 1, 106-118. [CrossRef]

32. Volkan, V. Chosen trauma: Unresolved mourning. In Bloodlines: From Ethnic Pride to Ethnic Terrorism; Volkan, V., Ed.; Farrar, Straus, \& Giroux: New York, NY, USA, 1997; pp. 36-49.

33. Hirschberger, G. Collective Trauma and the Social Construction of Meaning. Front. Psychol. 2018, 9, 1441. [CrossRef]

34. Boyer, M.C. The City of Collective Memory: Its Historical Imagery and Architectural Entertainments; Christine Boyer, M., Ed.; MIT Press: Cambrige, MA, USA, 1994.

35. Nora, P. Between memory and history: Les lieux de memoire. In Memory and Counter-Memory; University of California Press: Berkeley, CA, USA, 1989; pp. 7-24.

36. Lawson, B. The Language of Space/Bryan Lawson; Architectural Press: Oxford, UK, 2001.

37. Lowenthal, D. Past Time, Present Place: Landscape and Memory. Geogr. Rev. 1975, 65, 1-36. [CrossRef]

38. Tiwari, R. Space-Body-Ritual: Performativity in the City; Tiwari, R., Ed.; Lexington Books: Lanham, MD, USA, 2010.

39. Molavi, M.; Rafizadeh, I.M.; Rafizadeh, E.M. IS COLLECTIVE MEMORY IMPRESSED BY URBAN ELEMENTS? Manag. Res. Pract. 2017, 9, 14-27.

40. Kate Darian Smith, P.H. Memory and History in Twentieth-Century Australia; Darian-Smith, K., Hamilton, P., Eds.; Oxford University Press: Melbourne, VIC, Australia, 1994.

41. Halbwachs, M. On Collective Memory/Maurice Halbwachs Edited, Translated, and with an Introduction by Lewis A. Coser; Coser, L.A., Ed.; University of Chicago Press: Chicago, IL, USA, 1992.

42. Cotoi, A. Cultural Memory. In Philobiblon; University of California Press: Berkeley, CA, USA, 2015; Volume 20, pp. 247-253.

43. Li, N. Preserving Urban Landscapes as Public History: The Chinese Context. Public Hist. 2010, 32, 51-61. [CrossRef]

44. Hamilton, P. The Knife Edge: Debates about Memory and History. In Memory and History in Twentieth-Century Australia; Darian-Smith, K., Hamilton, P., Eds.; Oxford University Press: Melbourne, VIC, Australia, 1994; pp. 9-32.

45. Lak, A.; Hakimian, P. Collective memory and urban regeneration in urban spaces: Reproducing memories in Baharestan Square, city of Tehran, Iran. City Cult. Soc. 2019, 18, 100290. [CrossRef]

46. Leila Mahmoudi, F.; Marzieh, S.; Leila, S. Contextualizing Palimpsest of Collective Memory in an Urban Heritage Site: Case Study of Chahar Bagh, Shiraz-Iran. Archnet-IJAR 2015, 9, 218-231. [CrossRef]

47. Isidora, S. Spaces of Memory-“The presence of absence" cultural memory and oblivion mechanisms. Kultura (Skopje) 2015, 4, 87-94.

48. Legg, S. Memory and Nostalgia; Sage Publications Ltd.: London, UK, 2004; pp. 99-107.

49. Jahanbakhsh, H.; Koumleh, M.H.; Alambaz, F.S. Methods and Techniques in Using Collective Memory in Urban Design: Achieving Social Sustainability in Urban Environments. Cumhur. Univ. Fac. Sci. J. (CSJ) 2015, $36,13$.

50. Altman, I.; Low, S.M. Place Attachment; Altman, I., Low, S.M., Eds.; Plenum Press: New York, NY, USA, 1992.

51. Tuan, Y.-F. Space and Place: The Perspective of Experience; Tuan, Y.-F., Ed.; University of Minnesota Press: Minneapolis, MN, USA, 1979.

52. Relph, E. Place and Placelessness; A Revision of the Author's Thesis; Pion: London, UK, 1976. 
53. Mihaylov, N.; Perkins, D. Community Place Attachment and its Role in Social Capital Development. In Place Attachment: Advances in Theory, Methods and Applications; Manzo, L., Wright, P.D., Eds.; Routledge: London, UK, 2014; pp. 75-88.

54. Rowles, G.D. Place attachment among small town elderly. J. Rural Community Psychol. 1990, 11, 103-120.

55. Hay, R. Sense of place in developmental context. J. Environ. Psychol. 1998, 18, 5-29. [CrossRef]

56. Giuliani, M.V. Theory of attachment and place attachment. In Psychological Theories for Environmental Issues; Bonnes, M., Lee, T., Eds.; Routledge: London, UK, 2003; pp. 137-170.

57. Hidalgo, M.; Hernandez, B. Place attachment: Conceptual and empirical questions. J. Environ. Psychol. 2001, 21, 273-281. [CrossRef]

58. Ramkissoon, H.; Weiler, B.; Smith, L.D.G. Place attachment and pro-environmental behaviour in national parks: The development of a conceptual framework. J. Sustain. Tour. 2012, 20, 257-276. [CrossRef]

59. Ramkissoon, H.; Smith, L.D.G.; Weiler, B. Relationships between place attachment, place satisfaction and pro-environmental behaviour in an Australian national park. J. Sustain. Tour. 2013, 21, 434-457. [CrossRef]

60. Jaskiewicz, M. Place attachment, place identity and aesthetic appraisal of urban landscape. Polish Psychol. Bull. 2015, 46, 573-578. [CrossRef]

61. Kyle, G.T.; Mowen, A.J.; Tarrant, M. Linking place preferences with place meaning: An examination of the relationship between place motivation and place attachment. J. Environ. Psychol. 2004, 24, 439-454. [CrossRef]

62. Purwanto, E.; Harani, A.R. Understanding the place attachment and place identity in public space through the ability of community mental map. IOP Conf. Ser. Earth Environ. Sci. 2020, 402, 12024. [CrossRef]

63. Ujang, N.; Zakariya, K. Place Attachment and the Value of Place in the Life of the Users. Procedia Soc. Behav. Sci. 2015, 168, 373-380. [CrossRef]

64. Rubinstein, R.L.; Parmelee, P.A. Place Attachment: Attachment to Place and The Representation of the Life Course by The Eldery; Springer: New York, NY, USA, 1984.

65. Williams, D.R.; Patterson, M.E.; Roggenbuck, J.W.; Watson, A.E. Beyond the commodity metaphor: Examining emotional and symbolic attachment to place. Leis. Sci. 1992, 14, 29-46. [CrossRef]

66. Proshansky, H.M. The City and Self-Identity. Environ. Behav. 1978, 10, 147-169. [CrossRef]

67. Lewicka, M. Place attachment, place identity, and place memory: Restoring the forgotten city past. J. Environ. Psychol. 2008, 28, 209-231. [CrossRef]

68. Anton, C.E.; Lawrence, C. Home is where the heart is: The effect of place of residence on place attachment and community participation. J. Environ. Psychol. 2014, 40, 451-461. [CrossRef]

69. Raymond, C.M.; Brown, G.; Weber, D. The measurement of place attachment: Personal, community, and environmental connections. J. Environ. Psychol. 2010, 30, 422-434. [CrossRef]

70. Jorgensen, B.; Stedman, R. Sense of place as an attitude: Lakeshore owners attitudes toward their properties. J. Environ. Psychol. 2001, 21, 233-248. [CrossRef]

71. Cheshmehzangi, A.; Heat, T. Urban Identities: Influences on Socio-Environmental Values and Spatial Inter-Relations. Procedia Soc. Behav. Sci. 2012, 36, 253-264. [CrossRef]

72. Dodge, R.; Daly, A.P.; Huyton, J.; Sanders, L.D. The challenge of defining wellbeing. Int. J. Wellbeing 2012, 2, 222-235. [CrossRef]

73. Rees, G.; Goswami, H.; Bradshaw, J. Developing an Index of Children's SUBJECTIVE Well-being in England: Summary Report; The Children's Society, Ed.; The Children's Society: London, UK, 2010.

74. Zikmund, V. Health, well-being, and the quality of life: Some psychosomatic reflections. Neuro Endocrinol. Lett. 2003, 2, 401-403.

75. WHOQOL: Measuring Quality of Life. In Division of Mental Health and Prevention of Substance Abuse; World Health Organization: Geneva, Switzerland, 1997.

76. INEE. INEE Thematic Issue Brief: Psychosocial Well-Being. 2017. Available online: http://www. humanitarianinfo.org/iasc/content/products (accessed on 11 May 2020).

77. Tuan, Y.-F. The Significance of the Artifact. Geogr. Rev. 1980, 70, 462-472. [CrossRef]

78. Steele, F. The Sense of Place; CBI Pub Co: Boston, MA, USA, 1981.

79. Eyles, J. Senses of Place; Silverbrook Press: Warrington, UK, 1985.

80. Jackson, J.B. A Sense of Place, a Sense of Time; Jackson, J.B., Ed.; Yale University Press: New Haven, CT, USA, 1994. 
81. Relph, E. A Pragmatic Sense of Place. In Making Sense of Place; Al, F.V.E., Ed.; Australian National Museum: Canberra, ACT, Australia, 2008.

82. DeMiglio, L.; Williams, A.A. A Sense of Place, A Sense of Well-being. In Sense of Place, Health, and Quality of Life; John Eyles, A.W., Ed.; Ashgate: Aldershot, UK; Brookfield, VT, USA, 2008.

83. Cross, J.E. What is Sense of Place? In Proceedings of the 12th Headwaters Conference, Gunnison, CO, USA, 2-4 November 2001.

84. Hummon, D.M. Community attachment: Local sentiment and sense of place. In Place Attachment; Low, S.M., Altman, I., Eds.; Plenum Press: New York, NY, USA, 1992.

85. Williams, D.R.; Stewart, S.I. Sense of place: An elusive concept that is finding a place in ecosystem management. J. For. 1998, 66, 18-23.

86. Datel, R.E.; Dingemans, D.J. Environmental perception, historical preservation and sense of place. In Environmental Perception and Behaviour: An Inventory and Prospect; Saarinen, T.F., Seamon, D., Sell, J.L., Eds.; University of Chicago: Chicago, IL, USA, 1984.

87. Shamai, S.; Ilatov, Z. Measuring sense of place: Methodological aspects. Tijdschr. Voor Econ. Soc. Geogr. 2005, 96, 467-476. [CrossRef]

88. Eyles, J. Qualitative Approaches in the Investigation of Sense of place and Health Rellations. In Sense of Place, Health, and Quality of Life; Eyles, J., Williams, A., Eds.; Ashgate: Aldershot, UK; Burlington, VT, USA, 2008.

89. Lengen, C.; Kistemann, T. Sense of place and place identity: Review of neuroscientific evidence. Health Place 2012, 18, 1162-1171. [CrossRef]

90. Eisenhauer, B.W.; Krannich, R.S.; Blahna, D.J. Attachments to Special Places on Public Lands: An Analysis of Activities, Reason for Attachments, and Community Connections. Soc. Nat. Resour. 2000, 13, 421-441.

91. Williams, A.; Heidebrecht, C.; Demiglio, L.; Eyles, J.; Streiner, D.; Newblod, B. Developing a psychometric scale for measuring sense of place and health: An application of fact design. In Sense of Place, Health, and Quality of Life; Eyles, J., Williams, A., Eds.; Ashgate: Aldershot, UK; Burlington, VT, USA, 2008.

92. Woodward, K. Psychosocial Studies: An Introduction; Routledge: New York, NY, USA, 2015.

93. Heerwagen, J. Psychosocial Value of Space. 6 June 2017. Available online: http://www.wbdg.org/resources/ psychspace_value.php (accessed on 20 April 2020).

94. Kruger, L.E.; Farnum, J.O. Place-Based Planning: Innovations and Applications from Four Western Forests; Department of Agriculture United States: Washington, DC, USA, 2008.

95. Cheng, A.S.; Kruger, L.E.; Daniels, S.E. "Place" as an integrating concept in natural resource politics: Propositions for social science research agenda. Soc. Nat. Resour. 2003, 16, 87-104. [CrossRef]

96. Ahmed, S. The Cultural Politics of Emotion; Ahmed, S., Ed.; Edinburgh University Press: Edinburgh, UK, 2004.

97. Berberich, C. Affective Landscapes in Literature, Art and Everyday Life: Memory, Place and the Senses; Berberich, C., Campbell, N., Hudson, R., Eds.; Routledge: London, UK, 2016.

98. Lim, W.S.-W. Memories and urban places. Anal. Urban Trends Cult. Theory Policy Action 2000, 4, $270-277$. [CrossRef]

99. Lucy, W. If Planning Includes Too Much, Maybe It Should Include More. J. Am. Plan. Assoc. 1994, 60, 305-318. [CrossRef]

Publisher's Note: MDPI stays neutral with regard to jurisdictional claims in published maps and institutional affiliations.

(C) 2020 by the authors. Licensee MDPI, Basel, Switzerland. This article is an open access article distributed under the terms and conditions of the Creative Commons Attribution (CC BY) license (http://creativecommons.org/licenses/by/4.0/). 